\title{
Chronic cerebral hypoperfusion induces UCP2 expression by decreasing mitochondrial respiratory activities in aging rat brain
}

\author{
Minna Gao ${ }^{1,2,3^{*}}$, Li Liu' ${ }^{2,3,4}$, Linhui Wang ${ }^{2,3}$, Gang Yu ${ }^{4}, \mathrm{Yu} \mathrm{Li}^{2,3}$ \\ From 2011 International Conference on Molecular Neurodegeneration \\ Shanghai, China. 22-24 September 2011
}

\section{Background}

Chronic cerebral hypoperfusion and mitochondria dysfunction have been associated with various neurological and psychiatric diseases, including Alzheimer's disease and vascular dementia. UCP2 (The uncoupling protein 2) is one member of UCPs, which are a family of mitochondrial anion-carrier proteins. In this study, we intended to investigate the changes of UCP2 and mitochondrial respiratory activities in aging rat brains during chronic hypoperfusion of rats.

\section{Methods}

Chronic cerebral hypoperfusion was induced by ligating of the bilateral common carotid arteries (2VO). Fifty aging male Sprague-Dawley rats aged 12 months and weighing $460 \sim 530 \mathrm{~g}$, were randomly divided into five groups: a sham-operated group, 1 week, 2 weeks, 3 weeks and 4 weeks after $2 \mathrm{VO}$, with 10 rats in each group. The expressions of UCP2 protein in hippocampus were detected by immunohistochemistry. Mitochondrial cytochrome c oxidase activity was determined with a commercial enzyme assay kit.

\section{Results}

Blood flow was immediately reduced 1 day after $2 \mathrm{VO}$ $(\mathrm{P}<0.001)$, and did not return to the baseline level even after 28 days. UCP2 protein expression were significantly increased, and reached a peak at 21 days in the hippocampus and in cortex $(\mathrm{P}<0.01)$. Mitochondrial cytochrome $\mathrm{c}$ oxidase activity was decreased in hypoperfused groups, and had the lowest expression at 21 days after $2 \mathrm{VO}$ in hippocampus and cortex $(\mathrm{P}<0.001)$.

'Department of Pathology, Yongchuan Hospital, Chongqing Medical

University, China

Full list of author information is available at the end of the article

\section{Conclusion}

Our findings suggested that UCP2 might have important biological roles in protecting against hypoperfusion by decreasing mitochondrial respiratory activities. Further studies are needed to firmly establish this protective effect.

\section{Acknowledgements}

This study was supported by Program for Excellent talent in University of Chongqing (2010).

\section{Author details}

'Department of Pathology, Yongchuan Hospital, Chongqing Medical University, China. ${ }^{2}$ Institute of Neuroscience, Chongqing Medical University, China. ${ }^{3}$ Chongqing Key Laboratory of Neurobiology, China. ${ }^{4}$ Department of neurology, the first affiliated hospital, Chongqing Medical University, Chongqing 400016, China.

Published: 7 February 2012

doi:10.1186/1750-1326-7-S1-O6

Cite this article as: Gao et al:: Chronic cerebral hypoperfusion induces UCP2 expression by decreasing mitochondrial respiratory activities in aging rat brain. Molecular Neurodegeneration 2012 7(Suppl 1):O6.

Submit your next manuscript to BioMed Central and take full advantage of:

- Convenient online submission

- Thorough peer review

- No space constraints or color figure charges

- Immediate publication on acceptance

- Inclusion in PubMed, CAS, Scopus and Google Scholar

- Research which is freely available for redistribution

Submit your manuscript at www.biomedcentral.com/submit C Biomed Central 